\title{
Lung emphysema and lung cancer: what do we know about it?
}

\author{
Ramón A. Tubío-Pérez ${ }^{1,2}$, María Torres-Durán ${ }^{1,2}$, Mónica Pérez-Ríos ${ }^{3,4}$, Alberto Fernández-Villar ${ }^{1,2}$, \\ Alberto Ruano-Raviña ${ }^{3,4}$
}

${ }^{1}$ Pulmonary Department, Hospital Álvaro Cunqueiro, EOXI, Vigo, Spain; ${ }^{2}$ NeumoVigoI+i Research Group, Vigo Biomedical Research Institute (IBIV), Galicia, Spain; ${ }^{3}$ Department of Preventive Medicine and Public Health, University of Santiago de Compostela, Santiago de Compostela, Spain; ${ }^{4}$ CIBER de Epidemiología y Salud Pública, CIBERESP, Madrid, Spain

Contributions: (I) Conception and design: All authors; (II) Administrative support: All authors; (III) Provision of study materials or patients: All authors; (IV) Collection and assembly of data: All authors; (V) Data analysis and interpretation: All authors; (VI) Manuscript writing: All authors; (VII) Final approval of manuscript: All authors.

Correspondence to: María Torres-Durán. Pulmonary Department, Hospital Álvaro Cunqueiro, Estrada Clara Campoamor, 341, 36213, Vigo, Pontevedra, Spain. Email: mtordur@gmail.com.

\begin{abstract}
Emphysema and lung cancer (LC) are two diseases which share common risk factors, e.g., smoking. In recent years, many studies have sought to analyse this association. By way of illustration, we conducted a review of the scientific literature of the studies published to date, whose main designated aim was to demonstrate the relationship between emphysema and LC, and this association's influence on the histology, prognosis and molecular mechanisms responsible. We included over 40 studies (ranging from case-control and cohort studies to systematic reviews and meta-analyses), which highlight the association between emphysema and LC, independently of smoking habit. These studies also report a possible influence on histology, with adenocarcinoma being the most frequent lineage, and an association with poor prognosis, which affects both survival and post-operative complications. Oxidative stress, which generates chronic inflammatory status as well as the presence of certain polymorphisms in various genes (CYP1A1, TERT, CLPTM1L, ERK), gives rise-in the case of patients with emphysema-to alteration of cellular repair mechanisms, which in turn favours the proliferation of neoplastic epithelial cells responsible for the origin of LC.
\end{abstract}

Keywords: Lung cancer (LC); emphysema; chronic obstructive pulmonary disease (COPD); smoking habit; computed tomography (CT)

Submitted Feb 02, 2020. Accepted for publication May 22, 2020.

doi: $10.21037 / \mathrm{atm}-20-1180$

View this article at: http://dx.doi.org/10.21037/atm-20-1180

\section{Introduction}

Emphysema is a form of pulmonary damage due to alveolar wall destruction and dilation of the air spaces distal to the terminal bronchioles (1). Progression of this anatomic change leads to increases in lung volume, air trapping, impaired gas exchange and hypoxemia (2). Although its principal cause is exposure to tobacco smoke, there are also genetic causes, such as alpha-1 antitrypsin deficiency (3). Emphysema can sometimes present as chronic obstructive pulmonary disease (COPD), currently the fourth leading cause of death worldwide, with an estimated prevalence of $10 \%(4)$.
Lung cancer (LC) is one of the most frequent neoplasms in both sexes and the cancer with the highest mortality worldwide, with a 5-year survival rate of approximately $15 \%$ (5). Epidemiological studies indicate an expected increase in the number of cases in the coming years, in association with the rise in the overall number of smokers around the world (6).

Smoking habit is the principal risk factor for both emphysema and LC, something that suggests the existence of common disease development pathways (7). In patients who are never smokers, however, exposure to residential radon is the leading cause of LC (8), though to date it has not been possible to show an association between 
this exposure and development of emphysema and/or COPD. At present, computed tomography (CT) is the best method for non-invasive detection of emphysema (9). Its assessment can, in turn, be made by different techniques, including direct visualisation by a radiologist or automated analysis using software, though quantification by an expert radiologist appears to be better when it comes to studying its association with LC (10).

Accordingly, the aim of this review was twofold: to describe existing scientific evidence of the relationship between emphysema and LC, by examining the different mechanisms responsible; and to ascertain whether this relationship might influence the tumour's histological lineage and patients' prognosis.

\section{Emphysema and LC: search for an association}

\section{The beginning of the road}

The study of LC risk among patients with pulmonary emphysema is something that has been the subject of ongoing research in recent years. As far back as 1997, among 95 patients who underwent surgical resection of bullae, without presence of nodules or pleural thickening in the pre-operative CT scan, Venuta et al. (11) detected 4 patients (4.2\%) with peripheral foci of large cell carcinoma. On the basis of this result, the authors recommended complete excision of the bullae and meticulous histological examination of the surgical piece to rule out potential neoplastic foci. On studying 129 smokers who underwent pulmonary resection surgery for LC and comparing these patients to 281 voluntary controls, Cantlay et al. (12) observed that the presence of a polymorphism of the CYP1A1 gene (metabolising enzyme that intervenes in the activation of various carcinogens), consisting of the Ile genotype in homozygosity, led to susceptibility to develop $\mathrm{LC}$ in smokers with centriacinar emphysema $(\mathrm{OR}=2.45$; 95\% CI, 1.06-5.67), and that this association disappeared in the absence of emphysema $(\mathrm{OR}=0.52 ; 95 \% \mathrm{CI}, 0.16-1.77)$ or where emphysema was panacinar $(\mathrm{OR}=0.91 ; 95 \% \mathrm{CI}$, $0.20-4.10)$.

\section{Increasing the evidence}

Kishi et al. (13) conducted a case-control study at the Mayo Clinic (Rochester), aimed at ascertaining whether the presence of emphysema or bronchial obstruction amounted to an LC risk factor. Based on a sample of 1,520 participants in a year-long LC screening programme (inclusion criteria: age $\geq 50$ years with life expectancy $>5$ years; and history of smoking with accumulated consumption of $\geq 20$ packs-year, or ex-smoker of less than 10 years, without use of oxygen therapy) and using low-dose CT (LDCT) and quantitative analysis (threshold of $-900 \mathrm{HU}$ to differentiate emphysema from normal pulmonary tissue), they diagnosed 24 cases of LC, with each case being matched with 4 controls adjusted for sex, age and smoking habit (96 controls). In terms of LC, they observed an association solely with presence of bronchial obstruction with FEV1 (forced expiratory volume in 1 second) $\leq 40 \%$ (OR =9.6; 95\% CI, 1.5-60.1, $\mathrm{P}=0.016$ ), but not with presence of emphysema $(\mathrm{OR}=1.1 ; 95 \% \mathrm{CI}$, 0.6-1.9). The authors attribute their findings both to the method employed to assess emphysema by the LDCT chest scan used, and to the low attenuation threshold (-900 UH) set for detection of emphysema. Schabath et al. (14) examined the risk of different pulmonary diseases (asthma, bronchitis, emphysema, allergic rhinitis and pneumonia) in 1,553 patients with LC (85.1\% smoking habit) and 1,375 healthy volunteers (83.6\% smoking habit) in a case-control study undertaken in Texas from 1995 to 2003. The study included analysis of the polymorphisms of 2 genes [matrix metalloproteinase-1 (MMP-1) with polymorphism of the $1 \mathrm{G}$ and $2 \mathrm{G}$ alleles which act by encoding the recognition sites of transcription factor binding; and myeloperoxidase (MPO) with the A and $G$ alleles which participate in the different affinity for binding to the SP1 transcription factor]. Of all the respiratory diseases included, it was pulmonary emphysema that displayed the strongest association with risk of LC $(\mathrm{OR}=2.87 ; 95 \% \mathrm{CI}, 2.20-3.76)$, and within the group with emphysema, it was those patients with MMP-1 genotypes $1 \mathrm{G} / 1 \mathrm{G}+1 \mathrm{G} / 2 \mathrm{G}(\mathrm{OR}=2.58$; 95\% CI, 1.63-4.09) and $2 \mathrm{G} / 2 \mathrm{G}(\mathrm{OR}=4.45 ; 95 \% \mathrm{CI}, 2.34-8.47)$ and $\mathrm{MPO}$ genotypes $\mathrm{G} / \mathrm{A}+\mathrm{A} / \mathrm{A}(\mathrm{OR}=2.04 ; 95 \% \mathrm{CI}, 1.19-3.49)$ and $\mathrm{G} / \mathrm{G}(\mathrm{OR}=3.73 ; 95 \% \mathrm{CI}, 2.24-6.21)$. de Torres et al. (10) studied this association in a cohort of 1,166 participants in an LC screening programme (inclusion criteria: age $\geq 40$ years; smoking habit of $>10$ packs-year; and absence of symptoms of LC). Presence of emphysema was examined by LDCT and assessed by two expert radiologists, with emphysema being categorised into 4 groups [0-4], where 0 was equivalent to absence of emphysema, 4 was equivalent to over $75 \%$ of pulmonary emphysema, and $\geq 1$ was established as the cut-off point for presence of emphysema. The study protocol included spirometry and LDCT at the date of inclusion, followed by an annual LDCT for 
5 years. Of the 23 cases of LC diagnosed, 17 presented with emphysema in the LDCT, with 16 of these (94\%) displaying heterogeneous distribution and upper-lobe predominance. Incidence of emphysema was 25 cases per 1,000 persons/year, and an increase in LC risk was observed in patients with emphysema (OR $=3.33 ; 95 \% \mathrm{CI}, 1.41-7.85)$ and bronchial obstruction ( $\mathrm{OR}=4.83 ; 95 \% \mathrm{CI}, 2.05-11.41)$, with persistence of increased risk in the emphysema group without bronchial obstruction $(\mathrm{OR}=4.33 ; 95 \% \mathrm{CI}$, 1.04-18.16) after adjustment for age, sex and smoking habit, which indicates that emphysema is an LC risk factor regardless of the presence of airflow obstruction.

Wilson et al. (6) studied the presence of emphysema in a cohort of 3,638 subjects in an LC screening programme (the Pittsburgh Lung Screening Study/PLuSS). They included subjects aged 50-79 years with a history of smoking habit (>10 cigarettes/day for at least 25 years, without performance of a CT in the preceding 12 months). LDCT emphysema assessment was simultaneously performed by a pneumologist, general radiologist and thoracic radiologist, with emphysema being classified as minimal $(<10 \%)$, mild $(10-25 \%)$, moderate $(25-50 \%)$ or severe $(>50 \%)$. A total of 99 cases of LC $(2.7 \%)$ were diagnosed, and the multiple logistic regression analysis detected an association between risk and presence of bronchial obstruction (GOLD I-IV, $\mathrm{OR}=2.0995 \% \mathrm{CI}, 1.33-3.27$ ) and pulmonary emphysema $(\mathrm{OR}=3.56$; 95\% CI, 2.21-5.73), with it being noted that this association did not change after adjustment for GOLD class $(\mathrm{OR}=3.14 ; 95 \% \mathrm{CI}, 1.91-5.15)$. Maldonado et al. (15) conducted a case-control study, using 64 cases of LC obtained from a cohort of 1,520 participants in an LC screening programme [duration and inclusion criteria similar to those used by Kishi et al. (13)] and quantitative measurement of emphysema by CT with a threshold of $-900 \mathrm{UH}$, and 377 controls adjusted for sex, age and history of smoking habit. This study found an association between risk of LC and severe airflow obstruction $(\mathrm{FEV} 1 \leq 40)(\mathrm{OR}=2.84 ; 95 \% \mathrm{CI}, 1.09-7.38)$ but not between risk of $\mathrm{LC}$ and emphysema (OR $=1.042$; $95 \%$ CI, 0.816-1.329), and this absence of association was maintained in cases of severe emphysema $(>50 \%)$ (OR $=1.57$; 95\% CI, 0.73-3.37). The authors attribute the absence of association with emphysema: on the one hand, to the high number of women among the cases and controls (62\% and $61 \%$ respectively), unlike previous studies such as those by Wilson et al. (6) with $48.6 \%$ women or de Torres et al. (10) with $26 \%$, in view of the lower prevalence of emphysema in women than in men (16); and on the other hand, to the different methodology used for measurement of emphysema (quantitative analysis $v s$. visual analysis on CT). The absence of association in the group of men was attributed to the negligible number of men included and the ensuing low statistical power. Li et al. (17) conducted a case-control study with $565 \mathrm{LC}$ cases, and 450 controls adjusted for sex, age, smoking habit, race and residential area, drawn from an LC screening programme performed at the Mayo clinic across the period 1999-2004 (18). CT assessment of emphysema was performed by visual analysis, with classification into 3 categories, namely, $\geq 0 \%, \geq 5 \%$ and $\geq 10 \%$ of pulmonary tissue with emphysema. An association was found between emphysema and LC (OR $=2.79 ; 95 \%$ CI, 2.05-3.81), which grew stronger as the extent of emphysema increased ( $\geq 5 \%$ CT: OR $=3.80$; 95\% CI, 2.78 5.19; $\geq 10 \%$ CT: OR $=3.33 ; 95 \%$ CI, 2.30-4.82) and as age decreased $(<65$ years $\mathrm{OR}=4.62)$.

\section{The role of radiology: measuring association}

The importance of the method of CT detection and measurement of emphysema was analysed by Gierada et al. (19) in a retrospective study that included 279 cases of LC and 279 controls, both participants in the National Lung Screening Trial screening programme (20), with a median follow-up of 6.6 years (0.9-7.2). Quantitative measurement of emphysema (threshold $-950 \mathrm{HU}$ ) and the dimensions of the airway in the apical segments of the right upper lobe showed that attenuation of emphysema $<-950 \mathrm{HU}$ was associated with risk of $\mathrm{LC}(\mathrm{OR}=3.41 ; 95 \%$ CI, 1.78-6.94), and that there was no association between risk of LC and airway dimension. In 2012, Smith et al. (21) published a systematic review and meta-analysis analysing the risk of LC associated with CT-detected emphysema (comparison between visual analysis and densitometry). After application of exclusion criteria, 7 papers were selected in the systematic review and 5 in the meta-analysis which included 7,368 subjects. The results evidenced risk of LC among patients with emphysema detected by CT (OR $=2.11 ; 95 \%$ CI, 1.10-4.04), particularly among those with visual analysis $(\mathrm{OR}=3.50 ; 95 \% \mathrm{CI}, 2.71-4.51)$ as opposed to detection by densitometry $(\mathrm{OR}=1.16 ; 95 \% \mathrm{CI}$, $0.48-2.81)$.

Hohberger et al. (22) analysed the influence of the distribution of emphysema in different pulmonary regions and presence of pulmonary nodules $(\mathrm{PN})$ with risk of LC. They included 624 cases with malignant and 64 with benign $\mathrm{PN}$ characteristics, both groups drawn from the 
database of the National Heart, Lung, and Blood Institute's Lung Tissue Research Consortium (LTRC) (23), and the emphysema scores $(0=$ none; $1=$ mild: $1-25 \% ; 2=$ moderate: $26-50 \%$; $3=$ marked: $51-75 \%$; and $4=$ severe: $>75 \%$ ) were analysed by semiquantitative CT analysis performed by an expert radiologist. The authors showed that in cases with presence of malignant $\mathrm{PN}$, the probability of having a severe emphysema score was higher $(\mathrm{OR}=1.32 ; 95 \%$ CI, 1.11-1.62) than it was in localisations of benign PN ( $\mathrm{OR}=1.12 ; 95 \% \mathrm{CI}, 0.72-1.72$ ). Malignant $\mathrm{PN}$ were more frequently localised in the right lung $(\mathrm{OR}=1.46 ; 95 \% \mathrm{CI}$, $1.25-1.73)$, upper lobes and peripheral region $(\mathrm{OR}=3.71$; $95 \%$ CI, 3.06-4.51). In a sample of 78 patients with LC, Bae et al. (24) showed that risk of LC was higher in the upper lobes $(\mathrm{OR}=1.77 ; 95 \% \mathrm{CI}, 1.01-3.11, \mathrm{P}=0.048)$ and in pulmonary lobes with greatest emphysema severity, as classified by automated CT analysis (OR $=2.48 ; 95 \%$ CI, $1.48-4.15, \mathrm{P}<0.001)$. Working along these same lines, Lim et al. (25) analysed the relationship between CT-assessed emphysema severity (classification into grades $0-4$ ) and localisation of LC (central or peripheral) in 405 LC cases diagnosed across the period 2010-2014 (193 with diagnosis of COPD). They found that in patients with association of COPD and LC, the presence of high grades of emphysema [3-4] (OR =0.69; 95\% CI 0.51-0.92; $\mathrm{P}=0.016)$ and reduced FEV1/FVC (forced vital capacity) ratio $(<70 \%)$ was associated with a low risk of central localisation of LC (OR =0.94; 95\% CI, 0.89-0.99; $\mathrm{P}=0.024)$, after adjustment for age, smoking habit and spirometry. In contrast, patients with low grades of emphysema [0-2] had a three- to fourfold higher risk of central localisation of LC. In a sample of 62,124 participants, Henschke et al. (26) studied those who had undergone a CT chest scan as part of an LC screening programme (aged 40-90 years), and the distribution of LC cases by history of smoking habit and presence of emphysema. The group with the highest number of cases was that of active smokers with presence of pulmonary emphysema $(\mathrm{OR}=1.8 ; 95 \% \mathrm{CI}, 1.4-2.2)$, and the association between risk of $\mathrm{LC}$ and presence of emphysema was likewise maintained in ex-smokers (OR $=1.7 ; 95 \% \mathrm{CI}$, 1.3-2.2) and never-smokers (OR =6.3; 95\% CI, 2.4-16.9).

\section{The impact of the diagnosis of COPD}

Koshiol et al. (27) conducted a case-control study based on a sample of subjects drawn from the Environment and Genetics in Lung Cancer Etiology (EAGLE) (28) screening programme, with inclusion of 2,100 cases and
2,120 controls: of this total, 1,934 cases and 2,108 controls reported prior diagnosis of different chronic respiratory diseases (chronic bronchitis, emphysema, COPD). After adjustment for smoking habit $(83.2 \%$ cases and $67.9 \%$ controls), an association was found between LC and diagnosis of chronic bronchitis (OR =2; 95\% CI, 1.5-2.5), emphysema (OR $=1.9 ; 95 \% \mathrm{CI}, 1.4-2.8)$, and COPD $(\mathrm{OR}=2.5$; 95\% CI, 2-3.1). Wang et al. (29) carried out a case-control study and meta-analysis in south-east China with 1,069 cases of LC and 1,132 controls. An association was found, after adjustment for age, sex, family history of smoking habit, body mass index and smoking habit, with previous diagnosis of COPD (OR $=1.29 ; 95 \% \mathrm{CI}$, $1-1.68)$ and emphysema (OR $=1.55$; 95\% CI, 1.03-2.32). This association was stronger in the group of smokers (OR $=1.76 ; 95 \%$ CI, 1.07-2.90). In this same study, asthma was described as an LC risk-reduction factor $(\mathrm{OR}=0.29$; 95\% CI, 0.16-0.53). The meta-analysis included 35 studies $(22,010$ cases and 44,438 controls) with evidence of association in COPD (OR $=2.76$; 95\% CI, 1.85-4.11), emphysema (OR $=3.02 ; 95 \% \mathrm{CI}, 2.41-3.79)$ and chronic bronchitis (OR $=1.88$; 95\% CI, 1.49-2.36).

In 2016, Mouronte-Roibás et al. (30) performed a systematic review focusing on the relationship between COPD, emphysema and LC. Eleven studies (1 meta-analysis, 8 cohort studies, and 2 case-control studies) were included, showing an increase in risk of LC in patients with emphysema. This risk increased with higher tobacco use (increases of $0.6 \%$ for $\geq 30$ packs-year, $1.6 \%$ for $30-60$ packs-year, and $2.8 \%$ for persons consuming $\geq 60$ packs-year). The studies covered by this review included one published by Sanchez-Salcedo et al. (31), which studied the relevance of using emphysema as an LC risk factor, in addition to the criteria for selecting patients from the National Lung Screening Trial (NLST) in 2 LC screening programmes [the Pamplona International Early Lung Cancer Action/ P-IELCAP (32) with 3,061 participants, and the PLuSS (33) with 3,638 participants]. They found that, if NLST criteria alone had been used, as many as $39 \%$ of all LC cases would not have been diagnosed, and that when emphysema was added to the NLST criteria, the detection rate of incident cases of LC rose $(88 \%$ and $95 \%$ of the LC incidence rate in the P-IELCAP and PLuSS respectively), despite a $52 \%$ reduction in the number of patients being included for screening. This same group, Sanchez-Salcedo et al., reported the results of 14 years of experience of the P-IELCAP screening programme. Across this period, 60 LCs were diagnosed in 53 of the 2,989 participants, 
$60 \%$ of whom presented with emphysema on LDCT. COPD and emphysema were significant risk factors for LC (HR 4.52; 95\% CI, 2.50-8.18, $\mathrm{P}<0.001$ and HR 4.52; 95\% CI, 2.56-7.95, $\mathrm{P}<0.001$, respectively) (34).

Zhang et al.'s meta-analysis (35) included 18 prospective cohort studies with 12,442 cases of LC and a mean follow-up of 5 years (range, 1.5-20 years), and showed an association between risk of LC and COPD [summary relative risk $(\mathrm{SRR})=2.06 ; 95 \% \mathrm{CI}, 1.50-2.85, \mathrm{n}=4$ studies] and emphysema (SRR $=2.33 ; 95 \%$ CI, 1.56-3.49, $\mathrm{n}=4$ studies). Aamli Gagnat et al. (36) studied the amount of emphysema and airway wall thickness in quantitative CT, and analysed whether this was related to a higher risk of cancer: quantitative chest CT scans and spirometry performed on 947 subjects with history of smoking habit drawn from the GenKOLS study (37) showed that risk of cancer increased with greater emphysema severity [low attenuation area (LAA) $\geq 10 \%$ : OR $=3.33 ; 95 \% \mathrm{CI}$, 1.04-10.61 for LC, and OR $=2.10$; $95 \%$ CI, $1.14-3.87$ for non-pulmonary cancer] but not with airway wall thickness (OR $=0.39 ; 95 \%$ CI, $0.12-1.29$ for LC, and $\mathrm{OR}=0.82 ; 95 \%$ CI, 042-1.59 for non-LC).

\section{Type of emphysema and risk of LC}

Mouronte-Roibás et al. (38) analysed the relationship between type of emphysema and risk of LC in a study that included 169 cases of LC and COPD plus 74 controls, they found that presence of paraseptal emphysema and COPD increased the risk of $\mathrm{LC}(\mathrm{OR}=2.17 ; 95 \% \mathrm{CI}, 1.09-4.30 ; \mathrm{P}=0.03)$. In contrast, in a sample of 72 consecutive LC cases sourced from the Navarre University LC screening programme (Spain) with 3,477 participants, González et al. (39) detected that risk of $\mathrm{LC}$ was associated with presence of airflow obstruction ( $\mathrm{OR}=2.8 ; 95 \% \mathrm{CI}, 1.6-5.2)$ and centrilobular emphysema (OR $=34.3 ; 95 \%$ CI, 25.5-99.3), and that this risk decreased when associated with paraseptal emphysema $(\mathrm{OR}=4 ; 95 \% \mathrm{CI}, 3.6-34.9)$. In a case-control study comprising 2,283 LC cases and 2,323 controls, with detection of COPD in $32.8 \%$ of patients in the LC group, Wang et al. (40) found an association between risk and diagnosis of COPD (OR =2.88; 95\% CI, 2.48-3.14), and in the case of the phenotype, between risk and presence of emphysema (OR $=4.43$; 95\% CI, 2.85-6.88, $\mathrm{P}<0.001$ ), after adjustment for smoking habit.

Table 1 shows the main studies that analyse the emphysema-LC risk relationship. Figure 1 shows a chart depicting the different mechanisms responsible for the origin of LC in patients with emphysema.

\section{Emphysema and LC: mechanisms implicated}

The physiopathological mechanisms proposed to explain risk of LC in the presence of emphysema were initially described by reference to the association with smoking habit. Exposure to tobacco smoke causes a situation of oxidative stress, with production of various mediators (TGF- $\beta$, EGRF, IL-1-IL- 8 and G-CSF) that bring about a state of chronic inflammation and peripheral airway obstruction. This alteration gives rise to the phenomena of epithelial lesion and DNA damage, which cannot be remedied by genetic cellular repair mechanisms and result in neoplastic proliferation (41). Another possible pathway would be via dysfunction of mucociliary clearance, which is caused by emphysema and facilitates accumulation of carcinogens in areas without clearance, thereby favouring tumour growth at this level (17).

Investigation has focused on a number of genetic mechanisms that might be implicated in the association between pulmonary emphysema and LC. Alpha-1 antitrypsin is a glycoprotein which is mainly produced in the liver with antiprotease activity and whose deficiency is closely related to early development of pulmonary emphysema, especially in smokers: its association with higher risk of LC has also been described $(42,43)$. Other genetic pathways have been investigated, such as the case of a mutation in the CYP1A1 gene, which was analysed by Cantlay et al. (12) in surgical specimens of patients with emphysema and LC, showing that the presence of the IIe genotype in homozygosity was associated with higher risk of $\mathrm{LC}(\mathrm{OR}=2.03$; 95\% CI, 1.10-3.73). Glutathione S-transferase M1 deletion (44) and its relationship with centriacinar and panacinar emphysema has also been studied in 168 cases of LC. Similarly, variation in the locus $15 \mathrm{q} 24 / 25$ of the nicotinic acetylcholine receptor gene (nAChR) (45) or in the locus (5p15.33) of the TERT and CLPTM1L genes (46) has been associated with greater emphysema severity and risk of LC.

Lusk et al. (47) established the different genetic profiles of patients with LC by reference to the specific emphysema subphenotype, while activation of the ERK (extracellular signal-regulated kinase) oncogene has also been described as a nicotinic acetylcholine receptor (48). Rosas-Alonso et al. (49) analysed the effect of hypermethylation of microARN 7 (miR-7) (anti-oncogenic action) in a prospective study that included 30 smokers without airflow obstruction and 
Table 1 Characteristics of the main studies that analyse the direct relationship between emphysema and lung cancer

\begin{tabular}{|c|c|c|c|c|c|c|c|}
\hline $\begin{array}{l}\text { Author, journal, } \\
\text { year }\end{array}$ & Design & $\begin{array}{l}\text { Emphysema } \\
\text { measurement }\end{array}$ & $\mathrm{N}$ & $\begin{array}{l}\text { Emphysema in } \\
\text { LC/No LC, \% }\end{array}$ & Histology & $\begin{array}{l}\text { Pulmonary } \\
\text { function-LC, } \\
\text { OR }(95 \% \mathrm{Cl})\end{array}$ & $\begin{array}{l}\text { Emphysema-LC } \\
\text { association, OR } \\
(95 \% \mathrm{Cl})\end{array}$ \\
\hline $\begin{array}{l}\text { Wilson et al., } \\
\text { AJRCCM, } 2008\end{array}$ & Cohort & $\begin{array}{l}\text { Low-dose CT } \\
\text { (visual analysis) }\end{array}$ & $\begin{array}{l}99 \text { LC; 3,638 } \\
\text { participants }\end{array}$ & $75 / 40$ & ND & $\begin{array}{l}\text { GOLD I-IV; } \\
2.09(1.48-5.53)\end{array}$ & $3.14(1.91-5.15)$ \\
\hline $\begin{array}{l}\text { Maldonado et al., } \\
\text { Chest, } 2010\end{array}$ & Case-control & $\begin{array}{l}\mathrm{CT} \text { (quantitative } \\
\text { analysis) }\end{array}$ & $\begin{array}{l}64 \text { LC; } \\
377 \text { controls }\end{array}$ & $8.8 \pm 10.2 / 8.3 \pm 11.5$ & $\begin{array}{l}53 \% \text { ADC; } \\
21 \% \text { squamous }\end{array}$ & $\begin{array}{l}\text { FEV1 <40\%; } \\
2.84(1.09-7.38)\end{array}$ & $1.04(0.82-1.33)$ \\
\hline $\begin{array}{l}\text { Koshiol et al., } \\
\text { PLoS One, } 2009\end{array}$ & Case-control & $\begin{array}{l}\text { CT (EAGLE } \\
\text { study protocol) }\end{array}$ & $\begin{array}{l}2,100 \mathrm{LC} ; \\
2,120 \text { controls }\end{array}$ & $89.3 / 97$ & $\begin{array}{l}54.3 \% \text { ADC; } \\
10.9 \% \text { squamous }\end{array}$ & ND & $1.9(1.4-2.8)$ \\
\hline $\begin{array}{l}\text { Wang et al., PLoS } \\
\text { One, } 2012\end{array}$ & Case-control & $\begin{array}{l}\text { CT (method not } \\
\text { reported) }\end{array}$ & $\begin{array}{l}1,069 \text { LC; } \\
1,132 \text { controls }\end{array}$ & $7.2 / 3.9$ & ND & ND & $1.55(1.03-2.32)$ \\
\hline $\begin{array}{l}\text { Sanchez-Salcedo } \\
\text { et al., AJRCCM, } \\
2015\end{array}$ & Cohort & $\begin{array}{l}\text { Low-dose CT } \\
\text { (visual analysis) }\end{array}$ & $\begin{array}{l}\text { P-IELCAP } \\
=3,061 ; \\
\text { PLuSS =3,638 }\end{array}$ & $\begin{array}{l}\text { P-IELACP =24\%; } \\
\text { PLUSS }=43 \% *\end{array}$ & $\begin{array}{l}55 \% \text { ADC; } \\
22 \% \text { squamous }\end{array}$ & ND & $\begin{array}{l}\text { P-IELCAP =7.27 } \\
(5.57-9.50) ; \\
\text { PLuSS }=5.80 \\
(4.75-7.08)\end{array}$ \\
\hline
\end{tabular}

${ }^{\star}$, percentage of absolute emphysema in each study (P-IELCAP and PLuSS); ${ }^{* \star}$, association with paraseptal emphysema; ${ }^{\star \star \star}$, association with centrilobular emphysema. ADC, adenocarcinoma; ND, no data.

136 patients with COPD without evidence of LC. They observed a higher miR-7 hypermethylation value in patients with COPD and emphysema $(27.1 \% \pm 10.2 \%)$, as compared to patients with exacerbator phenotype $(19.4 \% \pm 9.9 \%$, $\mathrm{P}=0.004)$, chronic bronchitis $(17.3 \% \pm 9 \%, \mathrm{P}=0.002)$ or asthma-COPD overlap (ACO) $(16 \% \pm 7.2 \%, \mathrm{P}=0.01)$, after adjustment for clinical parameters and differences between phenotypes. Accordingly, the authors concluded that the presence of greater hypermethylation of miR-7 in patients with COPD and emphysema might account for the higher risk of $\mathrm{LC}$ in such patients.

\section{Emphysema and LC: influence on histology?}

There is no information available on the histology of LC in many of the studies that have investigated risk of LC in patients with emphysema, and those that do report this information do not always indicate the distribution of histological types by presence or absence of emphysema. In Kishi et al.'s study (13) the most frequent histology was adenocarcinoma in 14 cases $(58 \%)$, followed by squamous carcinoma in 6 (25\%) (24 LC in all). de Torres et al. (10) included 17 cases with emphysema and LC; the most frequent lineage-with 10 cases $(58 \%)$-was 


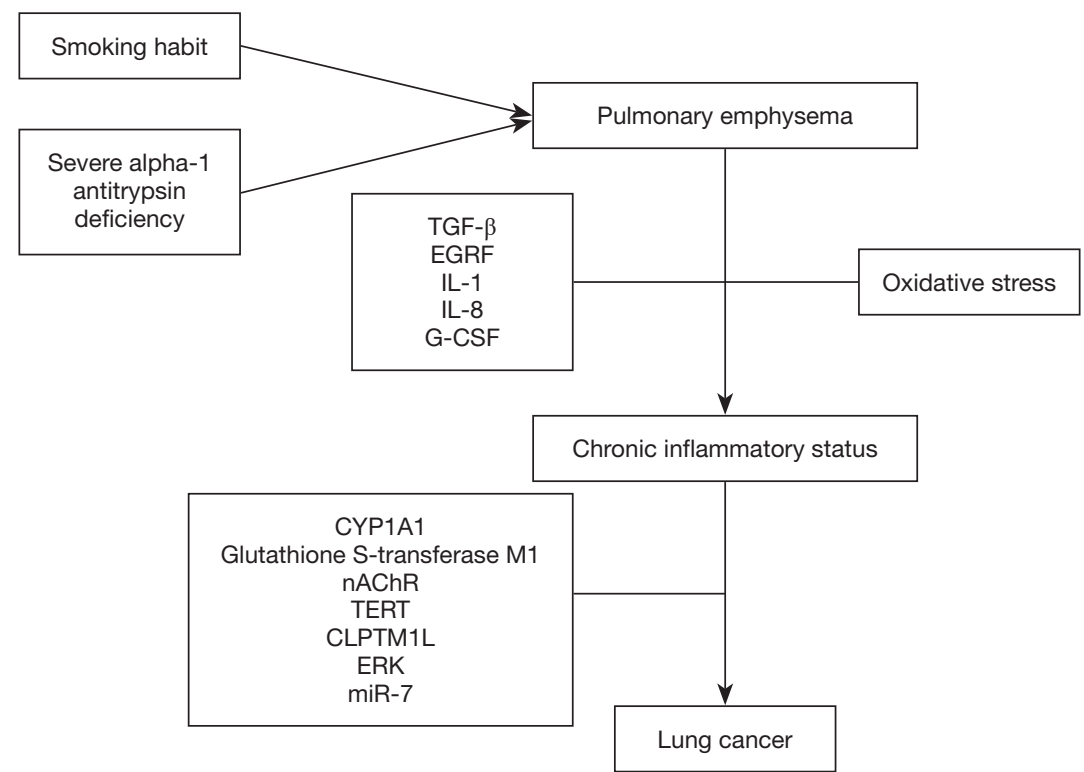

Figure 1 Description of the cascade of genetic and molecular mechanisms involved in the genesis of lung cancer in patients with emphysema.

adenocarcinoma. Maldonado et al. (15) included 64 LC cases with adenocarcinoma (53\%) and squamous carcinoma (21\%), as representing the most frequent histologies. Similarly, Li et al. (17) based their study on 565 cases, among which 259 (45.85\%) were adenocarcinoma and 159 (28.14\%) were squamous carcinoma. Smith et al.'s study (50) analysed the relationship between emphysema and different histologies in LC. It included 498 consecutive cases of LC across the period 2001-2009: overall, the most frequent lineage was adenocarcinoma (49\%) followed by squamous carcinoma (14\%). After adjustment for age, sex, COPD and smoking habit, presence of emphysema was solely associated with risk of squamous carcinoma ( $\mathrm{OR}=2.6 ; 95 \%$ CI, 1.4-4.8). Hohberger et al. (22) reported that of the total of LC cases ( $n=613), 98 \%$ were non-small cell LC, without furnishing specific data on histological lineage.

According to Lim et al. (25), the most frequent histology in the LC group with COPD was squamous carcinoma $(50 \%)$, followed by adenocarcinoma $(27.3 \%)$, while in the group without COPD, the most frequent histology was adenocarcinoma $(69.1 \%)$ followed by squamous carcinoma (17.4\%). Shin et al. (51) studied histological type in peripherally localised LC in 230 patients [2013-2015] with CT-detected pulmonary emphysema and airflow obstruction, among whom the most frequent histological type in peripheral areas without emphysema was adenocarcinoma (58\%), whilst in areas with emphysema it was small cell carcinoma (61\%) after adjustment for age, sex, smoking habit and FEV1. In Mouronte-Roibás et al.'s study (38), the most frequent histology associated with presence of paraseptal emphysema was adenocarcinoma (67.2\%), as was the case in González et al.'s study (39), with an adenocarcinoma frequency of $50 \%$. Wang et al.'s (40) found an association between the emphysema phenotype and the squamous (OR $=1.73 ; 95 \% \mathrm{CI}, 1.03-2.89)$ and small cell $(\mathrm{OR}=3.74$; 95\% CI, 1.64-8.53) lineages.

\section{Emphysema and LC: prognosis}

With the aim of establishing the prognosis of patients with emphysema and LC, the different papers focus not only on overall survival, but also on the prognosis after different forms of treatment. Hence, Pompeo et al.'s study (52), which analysed survival in 16 patients with stage I non-small cell LC and severe emphysema who underwent surgery, detected improvement at 24 months in dyspnea, FEV1, residual volume, and distance walked in the 6-minute walk test. Survival was similar to that of patients without LC undergoing lung volume reduction surgery (LVRS) (68\% vs. $82 \%$, $\mathrm{P}=$ non-significant). Subsequently, Martin-Ucar et al. (53) studied the prognosis of surgical resection by lobectomy and mediastinal dissection in 118 cases of stage I non-small cell LC across a period of 8 years [1997-2005]. Patients were classified into two groups by presence of heterogeneous 
emphysema of apical distribution: a group of 27 patients with predicted postoperative forced expiratory volume in 1 second (ppo FEV1 $<40 \%$ ), who would be suitable for LVRS but not for lobectomy according to guidelines, and a control group of 91 patients with ppo FEV $1>40 \%$, who would be suitable for lobectomy. Both groups had a mean follow-up of 57 months with differences in survival at 5 years (11\% in the LVRS group and 5\% in the control group, $\mathrm{P}=0.001$ ), showing lobectomy to be a safe technique, even in patients with more severe and higher-risk emphysema. Lee et al. (54) studied survival in 237 cases with stage I or II non-small cell LC who underwent surgical treatment, with presence of emphysema in $43.4 \%$. In this study, the patients without emphysema survived longer than did those with emphysema (mean $51.2 \pm 3.0$ vs. $40.6 \pm 3.1$ months, $\mathrm{P}=0.042$ ), with the multivariate analysis showing emphysema to be a mortality risk factor $(\mathrm{OR}=1.261 ; 95 \% \mathrm{CI}$, 0.748-2.125; $\mathrm{P}=0.384$ ). Similarly, when Bishawi et al. (55) examined the relationship between visually assessed emphysema severity on the one hand and LC localisation and 5-year survival on the other, they detected the highest LC risk and worst survival in areas of greatest emphysema severity. Kawakami et al. (56) too reported a relationship between 3D CT identification of emphysema and risk of postoperative complications $(\mathrm{P}=0.006)$. This mortality risk is also seen in the association between emphysema and airflow obstruction (57). Kim et al. (58) identified advanced risk of squamous carcinoma mortality due to presence of emphysema (HR =2.06; 95\% CI, 1.24-3.41; $\mathrm{P}=0.005)$.

Gullón et al. (59) analysed the prognoses in 353 cases of non-small cell LC and 110 cases of emphysema, and identified emphysema as an independent mortality risk factor (HR $=1.49 ; 95 \% \mathrm{CI}, 1.11-2.01)$. Zulueta et al. (60) studied risk of death in patients with COPD and LC by reference to presence of emphysema in a sample of 9,047 subjects who underwent low-dose CT: emphysema was detected in 2,637 patients (29\%), and proved to be a predictive factor of mortality in COPD (HR $=9.3 ; 95 \% \mathrm{CI}$, 4.3-20.2; $\mathrm{P}<0.0001)$ and $\mathrm{LC}(\mathrm{HR}=1.7 ; 95 \% \mathrm{CI}, 1.1-2.5$; $\mathrm{P}=0.013$ ) after adjustment for age and smoking habit.

Gao et al. (61) performed a meta-analysis of 7 observational studies, finding evidence of worse overall LC survival in the presence of emphysema ( $\mathrm{HR}=1.66 ; 95 \% \mathrm{CI}$, 1.25-2.22). This finding was likewise reported by Oelsner et al. (62) using CT-based detection of emphysema, and in addition to the higher risk of LC mortality ( $\mathrm{HR}=1.84$; 95\% CI, 1.09-3.12), was also reported for other respiratory diseases (HR $=2.94$; 95\% CI, 1.68-5.15).
Dai et al. (63) included 1,073 patients for surgical treatment of LC, dividing them into 3 groups, two by presence $(n=565)$ or absence of emphysema $(n=435)$, and a third categorised as non-surgical $(n=73)$. They detected worse results in pulmonary function, dyspnea and survival in the group with emphysema (HR $=1.73 ; 95 \% \mathrm{CI}$, $1.23-2.44)$. Insofar as microcytic LC is concerned, Lee et al. (64) reported that presence of emphysema measured semiquantitatively on CT was associated with worse prognosis in 149 cases of microcytic LC (HR $=1.85$; $95 \%$ CI, 1.14-3; $\mathrm{P}=0.012)$. In a recent retrospective study, Lim et al. (65) analysed the differences in radiological and pathological characteristics by presence of emphysema in a group with diagnosis of COPD and LC with histology of adenocarcinoma. They included 216 smokers, 102 of whom had diagnosis of COPD. The authors found that presence of emphysema was associated with a higher degree of histological aggressiveness $(\mathrm{P}=0.006)$ and solid mass lesions on CT $(\mathrm{P}<0.001)$. After adjustment for sex, age and smoking habit, presence of emphysema maintained an association with greater histological aggressiveness $(\mathrm{OR}=3.44 ; 95 \% \mathrm{CI}$, 1.12-10.56; $\mathrm{P}=0.03)$ and a higher frequency of solid lesions ( $\mathrm{OR}=6.19 ; 95 \% \mathrm{CI}, 1.80-21.25 ; \mathrm{P}=0.004)$ vis-á-vis the group without emphysema. Presence of emphysema was also associated with worse median survival (37 vs. 57.5 months, $\mathrm{P}=0.038)$.

\section{Future lines of research}

Despite growing evidence of the association between emphysema and LC, there are still unresolved aspects, stemming in part from the methodology used by the various studies. Hence, the different ways of measuring radiological emphysema (visual or automated), along with the different HU limits set for its detection, interfere with the emphysema detection rate and could thus influence the overall interpretation of results of studies that analyse its relationship with LC. The lack of studies that compare the risk of LC between groups having emphysema with COPD and emphysema without COPD is a line of research to be developed, in order to establish the role of emphysema as an independent risk factor for LC, without being associated with COPD, as is often the case.

\section{Conclusions}

In conclusion, emphysema is an independent risk factor for LC. This risk increases with higher rates of cigarette 
smoking. Pulmonary areas with greatest CT-assessed emphysema severity are associated with highest risk. The most frequent histological lineage in patients with emphysema and LC is adenocarcinoma, and the coexistence of emphysema and LC is associated with lower survival and higher risk of post-operative complications after LC surgery. Lastly, there are multiple potential pathways implicated in this association, though in all cases through chronic inflammatory status and anomalous cellular repair, which, along with polymorphisms in various genes, serve to trigger carcinogenesis.

\section{Acknowledgments}

This study is part of the work aimed at the completion of the PhD Degree of Ramón A. Tubío-Pérez.

Funding: None.

\section{Footnote}

Provenance and Peer Review: This article was commissioned by the Guest Editor (Bassam Redwan) for the series "Lung Emphysema" published in Annals of Translational Medicine. The article was sent for external peer review organized by the Guest Editor and the editorial office.

Conflicts of Interest: All authors have completed the ICMJE uniform disclosure form (available at http:// dx.doi.org/10.21037/atm-20-1180). The series "Lung Emphysema" was commissioned by the editorial office without any funding or sponsorship. The authors have no other conflicts of interest to declare.

Ethical Statement: The authors are accountable for all aspects of the work in ensuring that questions related to the accuracy or integrity of any part of the work are appropriately investigated and resolved.

Open Access Statement: This is an Open Access article distributed in accordance with the Creative Commons Attribution-NonCommercial-NoDerivs 4.0 International License (CC BY-NC-ND 4.0), which permits the noncommercial replication and distribution of the article with the strict proviso that no changes or edits are made and the original work is properly cited (including links to both the formal publication through the relevant DOI and the license). See: https://creativecommons.org/licenses/by-nc-nd/4.0/.

\section{References}

1. Standards for the diagnosis and care of patients with chronic obstructive pulmonary disease. American Thoracic Society. Am J Respir Crit Care Med 1995;152:S77-121.

2. Opitz I, Ulrich S. Pulmonary hypertension in chronic obstructive pulmonary disease and emphysema patients: prevalence, therapeutic options and pulmonary circulatory effects of lung volume reduction surgery. J Thorac Dis 2018;10:S2763-74.

3. Ogushi F, Hubbard RC, Vogelmeier C, et al. Risk factors for emphysema. Cigarette smoking is associated with a reduction in the association rate constant of lung alpha 1-antitrypsin for neutrophil elastase. J Clin Invest 1991;87:1060-5.

4. Miravitlles M, Soler-Cataluña JJ, Calle M, et al. Spanish Guidelines for Management of Chronic Obstructive Pulmonary Disease (GesEPOC) 2017. Pharmacological Treatment of Stable Phase. Arch Bronconeumol 2017;53:324-35.

5. Ferlay J, Soerjomataram I, Dikshit R, et al. Cancer incidence and mortality worldwide: sources, methods and major patterns in GLOBOCAN 2012. Int J Cancer 2015;136:E359-E386.

6. Wilson DO, Weissfeld JL, Balkan A, et al. Association of radiographic emphysema and airflow obstruction with lung cancer. Am J Respir Crit Care Med 2008;178:738-44.

7. Seijo LM, Zulueta JJ. Understanding the Links Between Lung Cancer, COPD, and Emphysema: A Key to More Effective Treatment and Screening. Oncology (Williston Park) 2017;31:93-102.

8. Torres-Durán M, Ruano-Ravina A, Parente-Lamelas I, et al. Lung cancer in never-smokers: a case-control study in a radon-prone area (Galicia, Spain). Eur Respir J 2014;44:994-1001.

9. Madani A, Keyzer C, Gevenois PA. Quantitative computed tomography assessment of lung structure and function in pulmonary emphysema. Eur Respir J 2001;18:720-30.

10. de Torres JP, Bastarrika G, Wisnivesky JP, et al. Assessing the relationship between lung cancer risk and emphysema detected on low-dose CT of the chest. Chest 2007;132:1932-8.

11. Venuta F, Rendina EA, Pescarmona EO, et al. Occult lung cancer in patients with bullous emphysema. Thorax 1997;52:289-90.

12. Cantlay AM, Lamb D, Gillooly M, et al. Association between the CYP1A1 gene polymorphism and susceptibility to emphysema and lung cancer. Clin Mol 
Pathol 1995;48:M210-M214.

13. Kishi K, Gurney JW, Schroeder DR, et al. The correlation of emphysema or airway obstruction with the risk of lung cancer: a matched case-controlled study. Eur Respir J 2002;19:1093-8.

14. Schabath MB, Delclos GL, Martynowicz MM, et al. Opposing effects of emphysema, hay fever, and select genetic variants on lung cancer risk. Am J Epidemiol 2005;161:412-22.

15. Maldonado F, Bartholmai BJ, Swensen SJ, et al. Are airflow obstruction and radiographic evidence of emphysema risk factors for lung cancer? A nested casecontrol study using quantitative emphysema analysis. Chest 2010;138:1295-302.

16. Dransfield MT, Washko GR, Foreman MG, et al. Gender differences in the severity of CT emphysema in COPD. Chest 2007;132:464-70.

17. Li Y, Swensen SJ, Karabekmez LG, et al. Effect of emphysema on lung cancer risk in smokers: a computed tomography-based assessment. Cancer Prev Res (Phila) 2011;4:43-50.

18. Yang P, Allen MS, Aubry MC, et al. Clinical features of 5,628 primary lung cancer patients: experience at Mayo Clinic from 1997 to 2003. Chest.2005;128:452-62.

19. Gierada DS, Guniganti P, Newman BJ, et al. Quantitative CT assessment of emphysema and airways in relation to lung cancer risk. Radiology 2011;261:950-9.

20. National Lung Screening Trial Research Team, Aberle DR, Berg CD, et al. The National Lung Screening Trial: overview and study design. Radiology 2011;258:243-53.

21. Smith BM, Pinto L, Ezer N, et al Schwartzman K. Emphysema detected on computed tomography and risk of lung cancer: a systematic review and meta-analysis. Lung Cancer 2012;77:58-63.

22. Hohberger LA, Schroeder DR, Bartholmai BJ, et al. Correlation of regional emphysema and lung cancer: a lung tissue research consortium-based study. J Thorac Oncol 2014;9:639-45.

23. Berry CE, Drummond MB, Han MK, et al. Relationship between lung function impairment and health-related quality of life in COPD and interstitial lung disease. Chest 2012;142:704-11.

24. Bae K, Jeon KN, Lee SJ, et al. Severity of pulmonary emphysema and lung cancer: analysis using quantitative lobar emphysema scoring. Medicine (Baltimore) 2016;95:e5494.

25. Lim J, Shin KM, Lee K, et al. Relationship Between Emphysema Severity and the Location of Lung Cancer in Patients With Chronic Obstructive Lung Disease. AJR Am J Roentgenol 2015;205:540-5.

26. Henschke CI, Yip R, Boffetta P, et al. CT screening for lung cancer: Importance of emphysema for never smokers and smokers. Lung Cancer 2015;88:42-7.

27. Koshiol J, Rotunno M, Consonni D, et al. Chronic obstructive pulmonary disease and altered risk of lung cancer in a population-based case-control study. PloS One 2009; 4:e7380.

28. Landi MT, Consonni D, Rotunno M, et al. Environment And Genetics in Lung cancer Etiology (EAGLE) study: an integrative population-based case-control study of lung cancer. BMC Public Health 2008;8:203.

29. Wang H, Yang L, Zou L, et al. Association between chronic obstructive pulmonary disease and lung cancer: a case-control study in Southern Chinese and a metaanalysis. PLoS One 2012; 7:e46144.

30. Mouronte-Roibás C, Leiro-Fernández V, Fernández-Villar A, et al. COPD, emphysema and the onset of lung cancer. A systematic review. Cancer Lett 2016;382:240-4.

31. Sanchez-Salcedo P, Wilson DO, de-Torres JP, et al. Improving selection criteria for lung cancer screening. The potential role of emphysema. Am J Respir Crit Care Med 2015;191:924-31.

32. Bastarrika G, García-Velloso MJ, Lozano MD, et al. Early lung cancer detection using spiral computed tomography and positron emission tomography. Am J Respir Crit Care Med 2005;171:1378-83.

33. Wilson DO, Weissfeld JL, Fuhrman CR, et al. The Pittsburgh Lung Screening Study (PLuSS): outcomes within 3 years of a first computed tomography scan. Am J Respir Crit Care Med 2008;178:956-61.

34. Sanchez-Salcedo P, Berto J, de-Torres JP, et al. Lung cancer screening: fourteen year experience of the Pamplona early detection program (P-IELCAP). Arch Bronconeumol 2015;51:169-76.

35. Zhang X, Jiang N, Wang L, et al. Chronic obstructive pulmonary disease and risk of lung cancer: a metaanalysis of prospective cohort studies. Oncotarget 2017;8:78044-56.

36. Aamli Gagnat A, Gjerdevik M, Gallefoss F, et al. Incidence of non-pulmonary cancer and lung cancer by amount of emphysema and airway wall thickness: a community-based cohort. Eur Respir J 2017;49:1601162.

37. Grydeland TB, Dirksen A, Coxson HO, et al. Quantitative computed tomography: emphysema and airway wall thickness by sex, age and smoking. Eur Respir J 2009;34:858-65. 
38. Mouronte-Roibás C, Fernández-Villar A, Ruano-Raviña A, et al. Influence of the type of emphysema in the relationship between COPD and lung cancer. Int J Chron Obstruct Pulmon Dis 2018;13:3563-70.

39. González J, Henschke CI, Yankelevitz DF, et al. Emphysema phenotypes and lung cancer risk. PloS One 2019;14:e0219187.

40. Wang W, Xie M, Dou S, et al. The link between chronic obstructive pulmonary disease phenotypes and histological subtypes of lung cancer: a case-control study. Int J Chron Obstruct Pulmon Dis 2018;13:1167-75.

41. Rooney C, Sethi T. The epithelial cell and lung cancer: the link between chronic obstructive pulmonary disease and lung cancer. Respiration 2011;81:89-104.

42. Yang P, Sun Z, Krowka MJ, et al. Alpha1-antitrypsin deficiency carriers, tobacco smoke, chronic obstructive pulmonary disease, and lung cancer risk. Arch Intern Med 2008;168:1097-103.

43. Ljujic M, Topic A, Nikolic A, et al. Identification of a rare p.G320R alpha-1-antitrypsin variant in emphysema and lung cancer patients. Genet Mol Biol 2010;33:5-8.

44. Harrison DJ, Cantlay AM, Rae F, et al. Frequency of glutathione S-transferase M1 deletion in smokers with emphysema and lung cancer. Hum Exp Toxicol 1997;16:356-60.

45. Lambrechts D, Buysschaert I, Zanen P, et al. The 15 q24/25 susceptibility variant for lung cancer and chronic obstructive pulmonary disease is associated with emphysema. Am J Respir Crit Care Med 2010;181:486-93.

46. Wauters E, Smeets D, Coolen J, et al. The TERTCLPTM1L locus for lung cancer predisposes to bronchial obstruction and emphysema. Eur Respir J 2011;38:924-31.

47. Lusk CM, Wenzlaff AS, Dyson G, et al. Whole-exome sequencing reveals genetic variability among lung cancer cases subphenotyped for emphysema. Carcinogenesis 2016;37:139-44.

48. Crosbie PAJ, Crosbie EJ, Aspinall-O'Dea M, et al. ERK and AKT phosphorylation status in lung cancer and emphysema using nanocapillary isoelectric focusing. BMJ Open Respir Res 2016;3:e00114.

49. Rosas-Alonso R, Galera R, Sánchez-Pascuala JJ, et al. Hypermethylation of Anti-oncogenic MicroRNA 7 is Increased in Emphysema Patients. Arch Bronconeumol 2020;56:506-13.

50. Smith BM, Schwartzman K, Kovacina B, et al. Lung cancer histologies associated with emphysema on computed tomography. Lung Cancer 2012;76:61-6.

51. Shin B, Shin S, Chung MJ, et al. Different histological subtypes of peripheral lung cancer based on emphysema distribution in patients with both airflow limitation and CT-determined emphysema. Lung Cancer 2017;104:106-10.

52. Pompeo E, De Dominicis E, Ambrogi V, et al. Quality of life after tailored combined surgery for stage I non-smallcell lung cancer and severe emphysema. Ann Thorac Surg 2003;76:1821-7.

53. Martin-Ucar AE, Fareed KR, Nakas A, et al. Is the initial feasibility of lobectomy for stage I non-small cell lung cancer in severe heterogeneous emphysema justified by long-term survival? Thorax 2007;62:577-80.

54. Lee SA, Sun JS, Park JH, et al. Emphysema as a risk factor for the outcome of surgical resection of lung cancer. $J$ Korean Med Sci 2010;25:1146-51.

55. Bishawi M, Moore W, Bilfinger T. Severity of emphysema predicts location of lung cancer and 5-y survival of patients with stage I non-small cell lung cancer. J Surg Res 2013;184:1-5.

56. Kawakami K, Iwano S, Hashimoto N, et al. Evaluation of emphysema using three-dimensional computed tomography: association with postoperative complications in lung cancer patients. Nagoya J Med Sci 2015;77:113-22.

57. Shin S, Park HY, Kim H, et al. Joint effect of airflow limitation and emphysema on postoperative outcomes in early-stage non small cell lung cancer. Eur Respir J 2016;48:1743-50.

58. Kim YS, Kim EY, Ahn HK, et al. Prognostic significance of CT-emphysema score in patients with advanced squamous cell lung cancer. J Thorac Dis 2016;8:1966-73.

59. Gullón JA, Suárez I, Medina A, et al. Role of emphysema and airway obstruction in prognosis of lung cancer. Lung Cancer 2011;71:182-5.

60. Zulueta JJ, Wisnivesky JP, Henschke CI, et al. Emphysema scores predict death from COPD and lung cancer. Chest 2012;141:1216-23.

61. Gao YH, Guan WJ, Liu Q, et al. Impact of COPD and emphysema on survival of patients with lung cancer: A meta-analysis of observational studies. Respirology 2016;21:269-79.

62. Oelsner EC, Carr JJ, Enright PL, et al. Per cent emphysema is associated with respiratory and lung cancer mortality in the general population: a cohort study. Thorax 2016;71:624-32.

63. Dai J, Liu M, Swensen SJ, et al. Regional Emphysema Score Predicting Overall Survival, Quality of Life, and Pulmonary Function Recovery in Early-Stage Lung Cancer Patients. J Thorac Oncol 2017;12:824-32. 
64. Lee HY, Kim EY, Kim YS, et al. Prognostic significance of CT-determined emphysema in patients with small cell lung cancer. J Thorac Dis 2018;10:874-81.

Cite this article as: Tubío-Pérez RA, Torres-Durán M, Pérez-Ríos M, Fernández-Villar A, Ruano-Raviña A. Lung emphysema and lung cancer: what do we know about it? Ann Transl Med 2020;8(21):1471. doi: 10.21037/atm-20-1180
65. Lim CG, Shin KM, Lim JK, et al. Emphysema is associated with the aggressiveness of COPD-related adenocarcinomas. Clin Respir J 2020;14:405-12. 